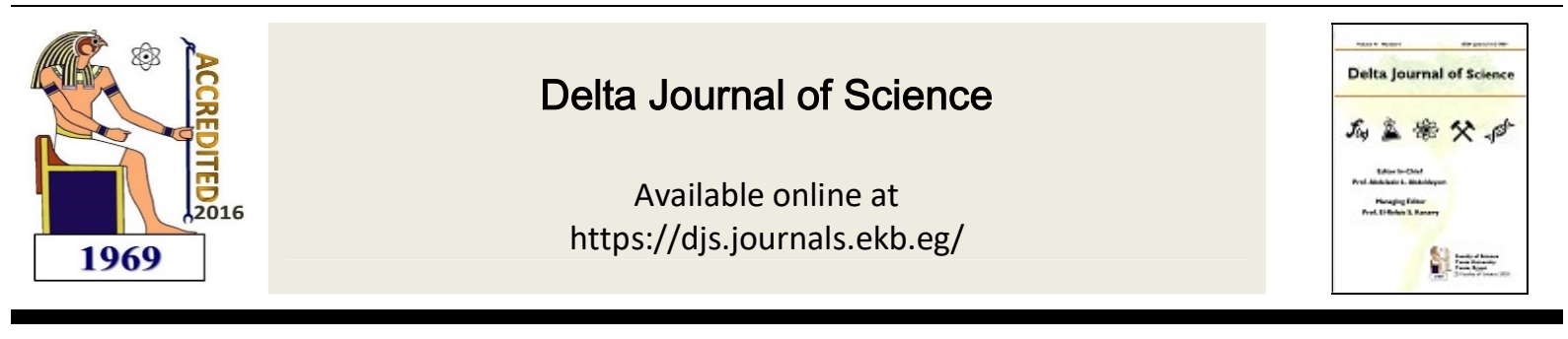

Research Article

BOTANY

\title{
Isolation and genetic identification of Cylindrotheca closterium algae from Alexandria coastal region
}

\author{
Rasha Ramadan ${ }^{1}$, Hanan Khairy ${ }^{2}$, Mohammed Halawa ${ }^{1}$ and Ashraf Haider ${ }^{1}$ \\ 1. Botany Department, Faculty of Science, University of Tanta. \\ 2. National Institute of Oceanography and Fishery, Alexandria.
}

KEY WORDS

Te Cylindrotheca closterium, diatoms, Bacillariophyta, $r b c L$ gene

\begin{abstract}
Text Cylindrotheca closterium alga belongs to family Bacillariaceae, order Bacillariales, class Bacillariophyceae and phylum Bacillariophyta. In this study Cylindrotheca closterium alga was isolated from Alexandria coastal region (Eastern Harbor) using two methods: dilution method and streak and spray plating technique. Isolated algal cells were cultured on Guillard $F_{2}$ liquid medium. Morphological identification was carried out by light microscope and scanning electric microscope. Algal cells were found to be wrapped by the raphe canal of valves, which is a typical characteristic of Cylindrotheca closterium shape. The cells contained two plastids lying next to each other along the longitudinal axis of the cell and apprised to one side of the cell with lobes extending onto the other sides, and the nucleus centrally in between. However, previous studies indicated some morphological variations during the life cycle of the alga.Genetic identification of Cylindrotheca closterium was carried out using ribulose-bisphosphate carboxylase gene $(r b c L)$ located in the plastids as molecular marker. Specific PCR primers were used to amplify $r b c L$ gene fragment from total genomic DNA extracted from Cylindrotheca closterium cells. Amplified rbcL (1177 bp) gene fragment was purified and sequenced. Nucleotide sequence was compared with Cylindrotheca sequences available in the GenBank. The Genetic distances and multi alignments were computed by Pairwise Distance method using Clusteral W software analysis. The nucleotide sequence of amplified $r b c L$ gene showed varied identity percentages $(81,80$ and $78 \%$ ) with other related sequences in the GenBank. This could be correlated to the observed morphological variations. Previous studies indicated high sequence divergences of $r b c L$ gene among Cylindrotheca isolates, and numerous nucleotide variations of $r b c L$ gene caused relatively few variation of deduced amino acid sequence. These results may indicate that Cylindrotheca closterium is a species complex as was previously evidenced by the variations of $r b c L$ gene.
\end{abstract}




\section{Introduction}

Text Diatoms are a main group of microalgae, and are highly diverse. More than 200 genera and 100000 species have been recorded in this group (Mann, 1989). Diatoms are widely distributed in seawater, fresh water, soil and moist surface. Although diatoms often aggregate into communities, they are unicellular and diverse in shapes with sizes varying from a few to hundreds of micrometers. These algae are the main primary producers in aquatic habitats and play a crucial role in global carbon cycle (Tréguer et al., 1995). The most prominent feature of diatoms is their silicic shells which enable them to sink to the bottom under some conditions. This performance makes their harvest easy, which are highly appreciated by algal culturing community.

Cylindrotheca closterium commonly found in neritic waters is best classified as tychopelagic or meroplanktonic since it exploits a halfplanktonic, half-benthic existence more completely than other species (Round, 1981). Meroplanktonic species are readily transported up into the water column where they survive and then return to the sediments. Under calm condition Cylindrotheca closterium cells are solitary and are characteristically needle-like, thin and elongated in shape. The ends of the cell tend to be drawn out from the center part. The frustules are only lightly silicified. The valves, including the keel and raphe canal, wrap around each other, forming a twisted frustule. As a result of the strong twist of the raphe system, the cells rotate and twirl as they move (Spaulding et al., 2008). Cylindrotheca closterium a marine diatom, grew on nitrate, ammonia, or urea as a sole source of nitrogen. When the three forms of nitrogen were offered in combination, ammonia was used first, followed by urea, and finally nitrate. In the seawater medium used, cell multiplication was always accompanied by a rapid rise in $\mathrm{pH}$ of the medium, regardless of the nitrogen source
(Grant et al., 1967). Identification of this species is based largely on morphological characteristics of the siliceous cell wall, such as shape of valve, ratio of length to width or diameter, number of star and fibulae, and number and type of labiate processes on valve. However, such identification may be difficult because of morphological similarity of different species and morphological variation during their life cycles. Benthic diatom Cylindrotheca closterium identified through both traditional morphological method and molecular phylogenetic method. For the molecular phylogenetic analyses, the $18 \mathrm{~S}$ rRNA and the ribulose bisphosphate carboxylase large subunit coding gene $(r b c L)$ were sequenced (Negrisolo et al., 2004). PCR has been used to effectively determine the presence or absence of an organism in a sample. In recent years, $r b c L$ gene the gene for the large subunit of the ribulose-bisphosphate carboxylase, located on the chloroplast genome, is an appropriate choice for inference of phylogenetic relationships at higher taxonomic levels. That gene was considered to be more useful than isozymes and restriction fragment length polymorphisms because of its slow synonymous nucleotide substitution rate in comparison with nuclear genes and its functional constraint that reduces the evolutionary rate of non-synonymous substitutions.

\section{Materials and methods}

The algal species used in this study was isolated from Alexandria coastal seawater and collected samples were cultured in the National Institute of Oceanography and Fisheries (NIOF), Alexandria, Egypt, and then identified morphologically by using binocular research microscope and Scanning Electron Microscope. Species was identified as Cylindrotheca closterium (diatom) according to (Hendy, 1964). Algal isolation was operated by the next two methods 


\section{Modified F2 medium (Guillard, 1975)}

Table 1: $F_{2}$ medium which contain major nutrients used to culture marine microalgae

\begin{tabular}{|c|c|c|}
\hline Major nutrient & Chemical formula & Concentration (g/l) \\
\hline 1-Nitrate & $\mathrm{NaNO}_{3}$ & $75.0 \mathrm{~g} / \mathrm{L}$ \\
\hline 2-Silicate & $\mathrm{Na}_{2} \mathrm{SiO}_{3} 9 \mathrm{H}_{2} \mathrm{O}$ & $30 \mathrm{~g} / \mathrm{L}$ \\
\hline 3-Phosphate & $\mathrm{NaH}_{2} \mathrm{PO}_{4} \cdot \mathrm{H}_{2} \mathrm{O}$ & $5.0 \mathrm{~g} / \mathrm{L}$ \\
\hline \multicolumn{3}{|l|}{ 4-Trace Metals } \\
\hline & $\mathrm{FeCl}_{3} \cdot 6 \mathrm{H}_{2} \mathrm{O}$ & $3.5 \mathrm{~g} / \mathrm{L}$ \\
\hline & $\mathrm{Na}_{2}$ EDTA & $4.36 \mathrm{~g} / \mathrm{L}$ \\
\hline \multicolumn{3}{|c|}{$\begin{array}{l}\text { Dissolve in } 900 \mathrm{ml} \text { of distilled } \mathrm{H}_{2} \mathrm{O} . \\
\text { Add } 1 \mathrm{ml} \text { of each of the following trace metal solutions. }\end{array}$} \\
\hline & $\mathrm{CuSO}_{4} .5 \mathrm{H}_{2} \mathrm{O}$ & $0.98 \mathrm{~g} / 100 \mathrm{ml}$ \\
\hline & $\mathrm{ZnSO}_{4} .7 \mathrm{H}_{2} \mathrm{O}$ & $2.20 \mathrm{~g} / 100 \mathrm{ml}$ \\
\hline & $\mathrm{CoCl}_{2} \cdot 6 \mathrm{H}_{2} \mathrm{O}$ & $1.00 \mathrm{~g} / 100 \mathrm{ml}$ \\
\hline & $\mathrm{MnCl}_{2} \cdot 4 \mathrm{H}_{2} \mathrm{O}$ & $18.00 \mathrm{~g} / 100 \mathrm{ml}$ \\
\hline & $\mathrm{Na}_{2} \mathrm{MoO}_{4} \cdot 2 \mathrm{H}_{2} \mathrm{O}$ & $0.63 \mathrm{~g} / 100 \mathrm{ml}$ \\
\hline \multicolumn{3}{|c|}{ Add $1 \mathrm{ml}$ per liter of seawater of the above solutions 1-3. } \\
\hline \multirow[t]{4}{*}{ 5-Vitamins } & & \\
\hline & Biotin & $1.0 \mathrm{mg}$ \\
\hline & $\mathrm{B}_{12}$ & $1.0 \mathrm{mg}$ \\
\hline & Thiamin $\mathrm{HCl}$ & $20.0 \mathrm{mg}$ \\
\hline
\end{tabular}

\section{Four stock solutions}

For all solutions, use sterilized distilled deionized water.
1. $\mathrm{NaNO}_{3}$ stock solution
$75 . \mathrm{Og} / \mathrm{L}$
2- $\mathrm{Na}_{2} \mathrm{SIO}_{3} .9 \mathrm{H}_{2} \mathrm{O}$
$33.0 \mathrm{~g} \backslash \mathrm{l}$
3. $\mathrm{NaH}_{2} \mathrm{PO}_{4}$ stock solution
$5.0 \mathrm{~g} / \mathrm{L}$

$10 \mathrm{ml}$ of $\mathrm{NaH}_{2} \mathrm{PO}_{4}$ will be added to every litre of $\mathrm{F} 2$ medium when used.

\section{Trace Metals stock solution}

To distilled water add the following:

$\mathrm{Na}_{2}$ EDTA

$4.36 \mathrm{~g} / \mathrm{L}$

$\mathrm{FeCl}_{3} .6 \mathrm{H}_{2} \mathrm{O}$ (Ferric Chloride)

$3.15 \mathrm{~g} \mid \mathrm{L}$

Primary Metals Stocks (below) $1 \mathrm{ml}$ of each of the five Major nutrients. 


\section{The dilution method}

This technique is used mainly for the isolation of microflagellates according to (Stein, 1973). Its basic principle is to dilute a portion of natural seawater community, dominated by the desired species, to reduce its density to few cells per $\mathrm{ml}$. One $\mathrm{ml}$ portion is dispensed into each of many small tubes or conical flasks of $10-25 \mathrm{ml}$ capacity containing sterilized natural marine seawater medium. The process is repeated several times until a successful unialgal culture is obtained.

Streak and spray plating technique

This technique was used mainly to isolate the diatom species. Algae were allowed to grow on solidified medium (natural filtered seawater, autoclaved and solidified with $1-1.5 \%$ agar). The natural algal collection was either dropped near the periphery of the agar or sprayed into the solidified agar. After streaking or spraying, the algal suspension on the solidified agar, petri-dishes were covered, inverted, and incubated for 4-8 days under suitable growth conditions of light (3000 Lux) and temperature $\left(25 \pm 1{ }^{\circ} \mathrm{C}\right)$. Plates were observed with a stereomicroscope and the desired colonies that are free of other organisms were removed using a fine capillary pipette or fine wire needle, and placed in a drop of sterile seawater medium on a cover glass, and then observed under the high power objective of compound microscope to make sure that the isolated species is free of contamination. The specimen is then removed to fresh sterile seawater medium and the technique was repeated several times until monoalgal species was isolated. Cultures were purified or at least its contamination minimized as follows:

About $10-50 \mathrm{ml}$ were taken from the algal liquid culture and centrifuged at $1500 \mathrm{rpm}$ for 1 minute. The supernatant that contained bacteria was decanted, whereas the pellet was resuspended in fresh sterilized liquid medium and centrifuged again at the same speed. This process was repeated for at least 10 times. Finally, the diatom cells were spread on solid medium with inoculating needle. From the purified cells, one cell was taken by sterilized capillary pipette into culture flask containing liquid medium.
Cultivation conditions: One hundred $\mathrm{ml}$ sterilized Erlenmeyer flasks were used as culture vessels. Into each flask $30 \mathrm{ml}$ of the autoclaved medium were used. The culture flasks were inoculated and kept under continuous illumination using daylight fluorescent tubes at an intensity of 3000 lux. The temperature was maintained at $25 \pm 1{ }^{\circ} \mathrm{C}$. The cultures of the species were shaken carefully by hand from time to time and before each sampling. All experiments were done in triplicate; the initial inoculum used throughout this investigation was about $100 \times 10^{3}$ cells $/ \mathrm{ml}$ of the species.

\section{Electron Microscope Examination:}

The preparation of algal samples for examination by Scanning Electron Microscope (SEM) was done as follow:

The samples were treated with nitric acid $70 \%$ and sulfuric acid $99 \%$ and gently heated for $30 \mathrm{~min}$. This quite drastic preparation method proved necessary to ensure sufficient cleaning of the material for scanning electron microscope (SEM). Cleaned material was mounted on SEM stubs, coated with gold and examined using a JEOL JSM5300 Scanning Electron Microscopy (Tomas, 1997).

Molecular identification

\section{DNA extraction}

Total genomic DNA of the specie was used according to manufacturer protocol of Omega Co. D3396-01 (USA.LMt.). The sample was transferred into a nuclease-free $1.5 \mathrm{ml}$ micro centrifuge tube and the volume of the sample was brought up to $250 \mu \mathrm{l}$ with $10 \mathrm{mM}$ Tris- $\mathrm{HCl}$, then, $25 \mu$ of elution buffer were added and the mixture was vortexed and incubated at $70^{\circ} \mathrm{C}$ for $10 \mathrm{~min}$. After incubation $250 \mu \mathrm{l}$ of $100 \%$ ethanol was added and vortexed to mix thoroughly. The HiBind ${ }^{\circledR}$ DNA Mini Column was inserted into a $2 \mathrm{ml}$ Collection Tube. The entire sample was transferred to the HiBind ${ }^{\circledR}$ DNA Mini Column including any precipitates that may have formed. Centrifuge at maximum speed $(\geq 10.000 \mathrm{x}$ g) for $1 \mathrm{~min}$. The filtrate was discarded and the collection tube was resumed.500 $\mu$ HBC Buffer was added. Centrifuge at maximum speed for 30 sec. The filtrate was discarded and tube was 
collected. The HiBind ${ }^{\circledR}$ DNA Mini Column was inserted into a new $2 \mathrm{ml}$ collection tube, then $700 \mu \mathrm{l}$ DNA Wash Buffer was added. Centrifuge at maximum speed for $30 \mathrm{sec}$. The filtrate was discarded and the collection tube was reused. Wash steps were repeated for a second DNA. The empty HiBind ${ }^{\circledR}$ DNA Mini Column was centrifuged at maximum speed for 2 min to dry the column. The HiBind ${ }^{\circledR}$ DNA Mini Column was transferee into a nuclease-free $1.5 \mathrm{ml}$ micro centrifuge tube, 50 to $200 \mu \mathrm{l}$ Elution Buffer was added and heated to $70^{\circ} \mathrm{C}$., seated at room temperature for $2 \mathrm{~min}$, then centrifuged at maximum speed for $1 \mathrm{~min}$. Steps were repeated for a second elution. Eluted DNA was stored at $-20^{\circ} \mathrm{C}$ until used.

\section{PCR amplification Conditions}

Specific DNA was amplified through Gene Amp Polymerase Chain Reaction (Creacon, Thermo cycler, Holand) system cycler. The cycling parameters initiated at $94^{\circ} \mathrm{C}$ for $4 \mathrm{~min}$, followed by 30 cycles of denaturing at $94^{\circ} \mathrm{C}$ for $30 \mathrm{sec}$, annealing at $55^{\circ} \mathrm{C}$ for $60 \mathrm{sec}$, and extension at $72^{\circ} \mathrm{C}$ for $90 \mathrm{sec}$, and an extra extension at $72^{\circ} \mathrm{C}$ for $10 \mathrm{~min}$ (Haitao et al. 2007).

Table2: Primer sequences used in $r b c L$ gene isolation

\begin{tabular}{|l|l|l|l|}
\hline Primers & Sequences & Tm value & GC $\%$ \\
\hline$r b c \mathrm{~L}-\mathrm{F}$ & CGKTACGAATCTGGWG & 43.06 & 57 \\
\hline$r b c \mathrm{~L}-\mathrm{R}$ & CCAATWGTACCACCACCRAAT & 54.86 & 47 \\
\hline
\end{tabular}

\section{Detection of the amplification products}

$1.5 \%$ agarose solution was prepared by adding $0.75 \mathrm{~g}$ agarose to $50 \mathrm{ml}$ of $1 \mathrm{x}$ TBE electrophoresis buffer in $50 \mathrm{ml}$ flask. Heating in a microwave oven then dissolved the agarose. The agarose was cooled in $50^{\circ} \mathrm{C}$. A comb was inserted in electrophoresis bed and the agarose was poured in it. Great care should be taken during pouring of the agarose to avoid bubbles formation. The gel solidified within $15 \mathrm{~min}$ and became cloudy, the electrophoresis apparatus was filled with the electrophoresis buffer and the comb was removed creating 6 or 10 wells for sample application. Electrodes were connected to the power supply and the later was turned on. It was adjusted at 80 Volts for $100 \mathrm{~min}$. The gel was removed from its bed and transferred to the gel staining tray for staining with Ethidium bromide for $30 \mathrm{~min}$ followed by 20 min distain in distilled water. Specific DNA bands were eluted from agarose gel. Resultant PCR products were purified with Micro spin filters (E.Z.N.A. ${ }^{\circledR}$ Gel Extraction Kit, D250001, OMEGA bio-tek, USA) and quantified spectrophotometrically. Sequence analysis was carried out using the ABI PRISM ${ }^{\circledR} 3100$ Genetic Analyzer (Micron-Corp.Korea).Gel documentation system (Geldoc-it, UVP, England), was applied for data analysis using Total lab analysis software, (ww.totallab.com), (Ver.1.0.1). Aligned sequences were analyzed on NCBI website (http://www.ncbi.nlm.nih.gov/webcite) using BLAST to confirm their identity. The Genetic distances and Multi alignments were computed by Pairwise Distance method using ClusteralW software analysis (www.ClusteralW.com). The nucleotide sequences were also compared with Cylindrotheca sequences available in the GenBank.

\section{Results}

\section{Algal purification and identification}


The algal species was isolated from Alexandria coastal seawater and identified as Cylindrotheca closterium (diatoms) according to (Hendy, 1964). The algal species was isolated using the dilution method and streak and spray plating technique according to (Stein, 1973). Modified F2 media (Guillard, 1975) was used to culture the algal species. The algal species was examined under light microscope (Fig 1). The specie of Cylindrotheca was motile, unicellular and thin in shape characterized by having cylindrical frustule which was fusiform. It was needle-like with a swollen center and two ends of the cell extended far from the center of the cell, The cell was linear to lanceolate, tapering to very long projection, there are many bands on the frustule twisted around each other in the rostrate ends; rostrate apices were extremely short barely seen under LM. The cells contained two plastids lying next to each other along the longitudinal axis of the cell and apprised to one side of the cell with lobes extending onto dividing both plastids without any obvious preceding plastid rearrangement, The central section of each cell contained 2 flat chromatophores in the middle of the cell, one on either side of the nucleus, lying along the cell wall, not extending into the ends, The purified algae were about $50 \mu \mathrm{m}$ in length. The chromatophore of the purified algae was in the middle of the cell. Under scanning electric microscope at magnification power $1600 \mathrm{x}$ and $3000 x$, the cell was found to be wrapped by the raphe canal of valves, which is a typical characteristic of Cylindrotheca closterium. The algal cell moved around when water streamed through the raphe canal, and divided longitudinally along the raphe canal as shown in ( Fig2).
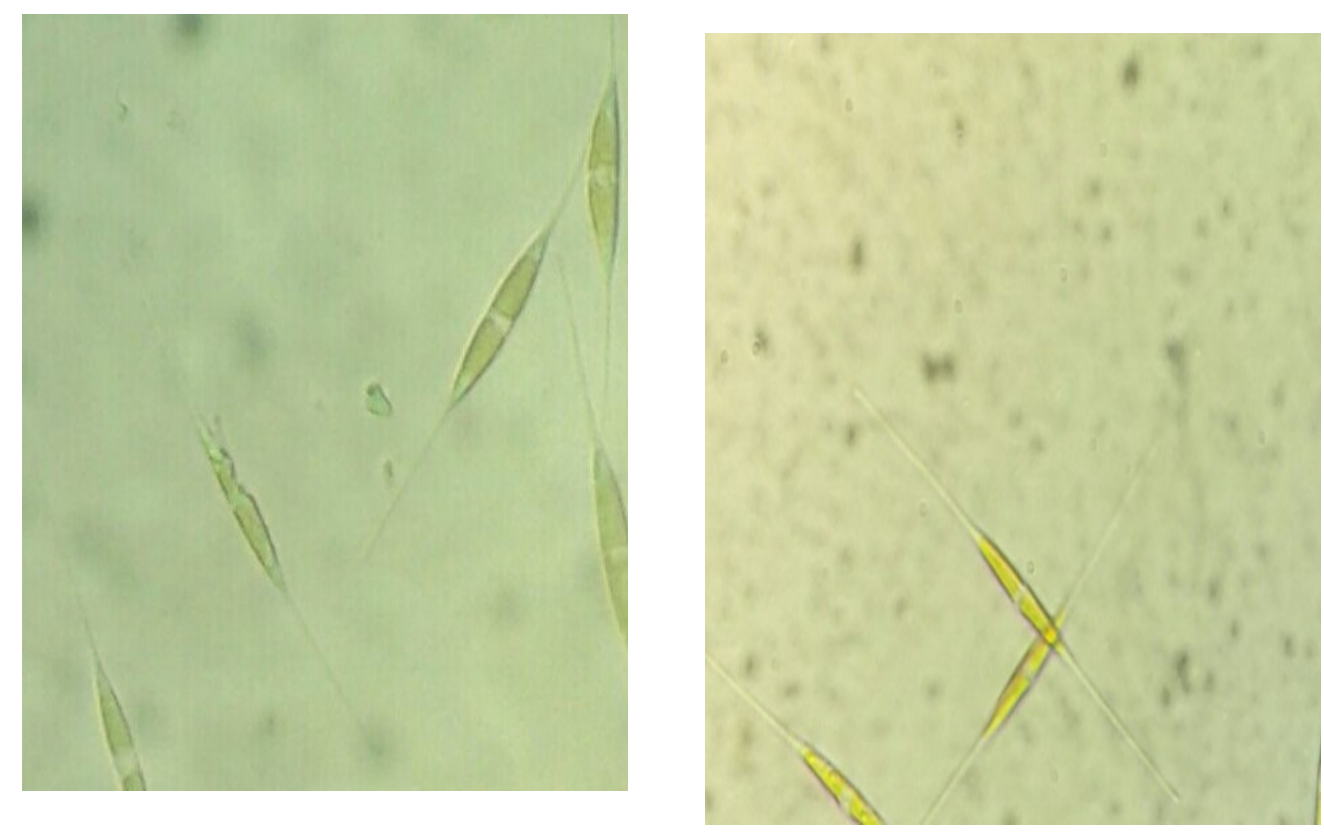

Fig (1): The cells of Cylindrotheca closterium as shown under light microscope showing cylindrical shape with two long ends and the bright pink color (Magnification power 40x). 

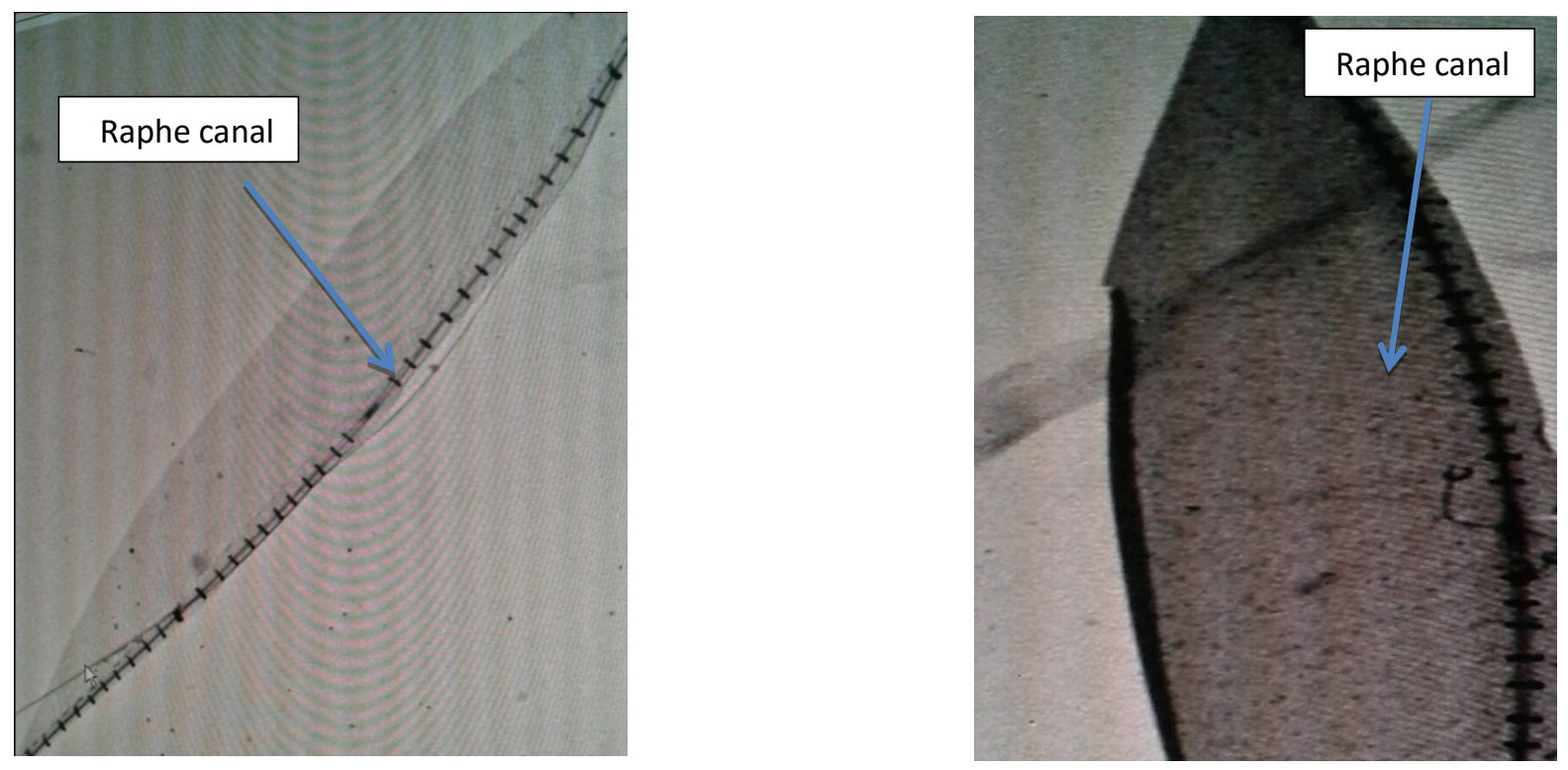

Fig (2): Cells of Cylindrotheca closterium as shown under Transmission Electron Microscope (TEM) showing presence of raphe canal (Magnification power $3000 \mathrm{x}$ ).
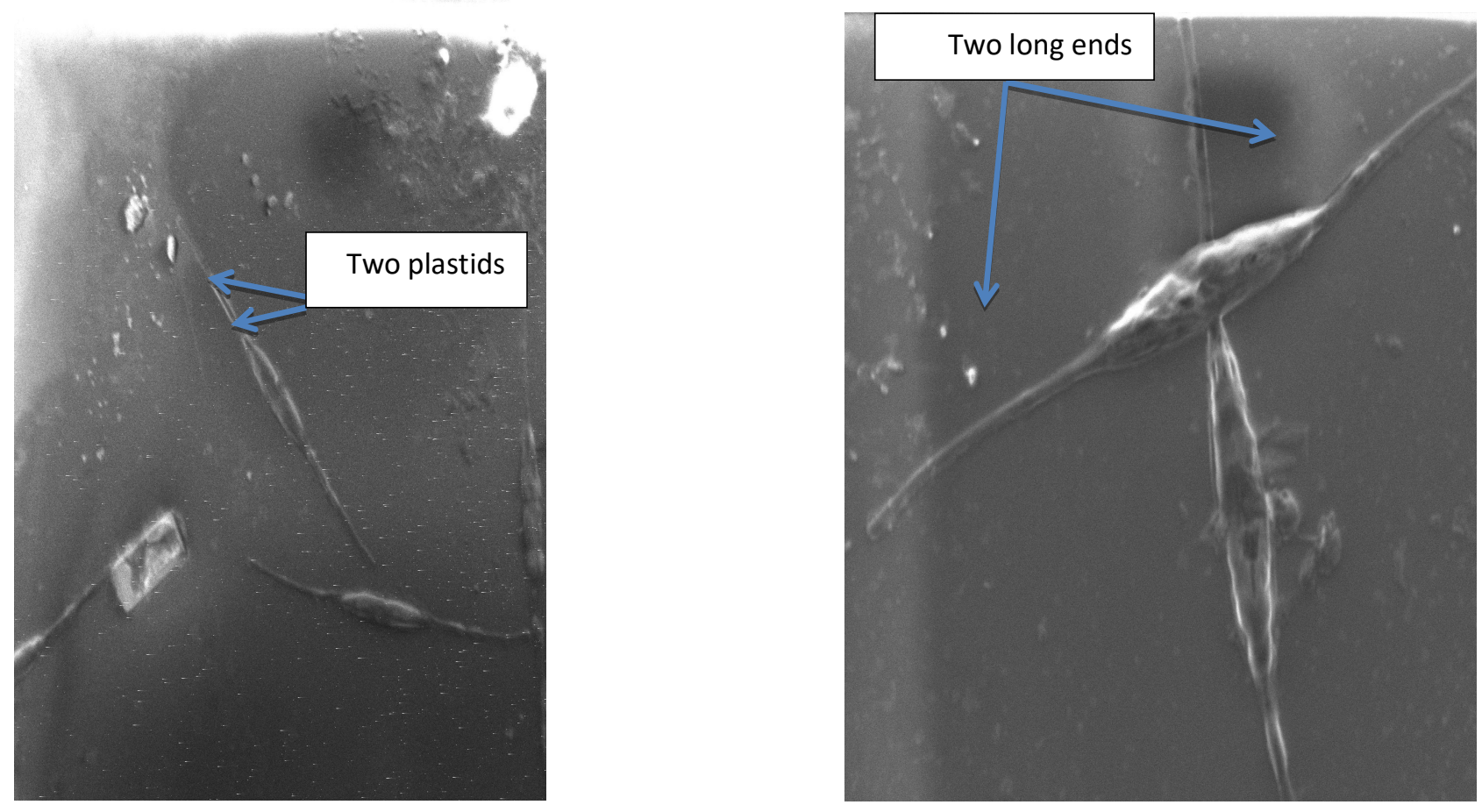

Fig (3) Cells of Cylindrotheca closterium as shown under Scanning Electron Microscope (SEM) indicating presence of two plastids and two long ends.

(Magnitic power 1500, 3000) 
DNA extraction and identification

\section{0 bp ladder}

\section{0 bp}

1000 bp

900 bp

800 bp

700 bp

600 bp

500 bp

$400 \mathrm{bp}$

$300 \mathrm{bp}$

$200 \mathrm{bp}$

$100 \mathrm{bp}$

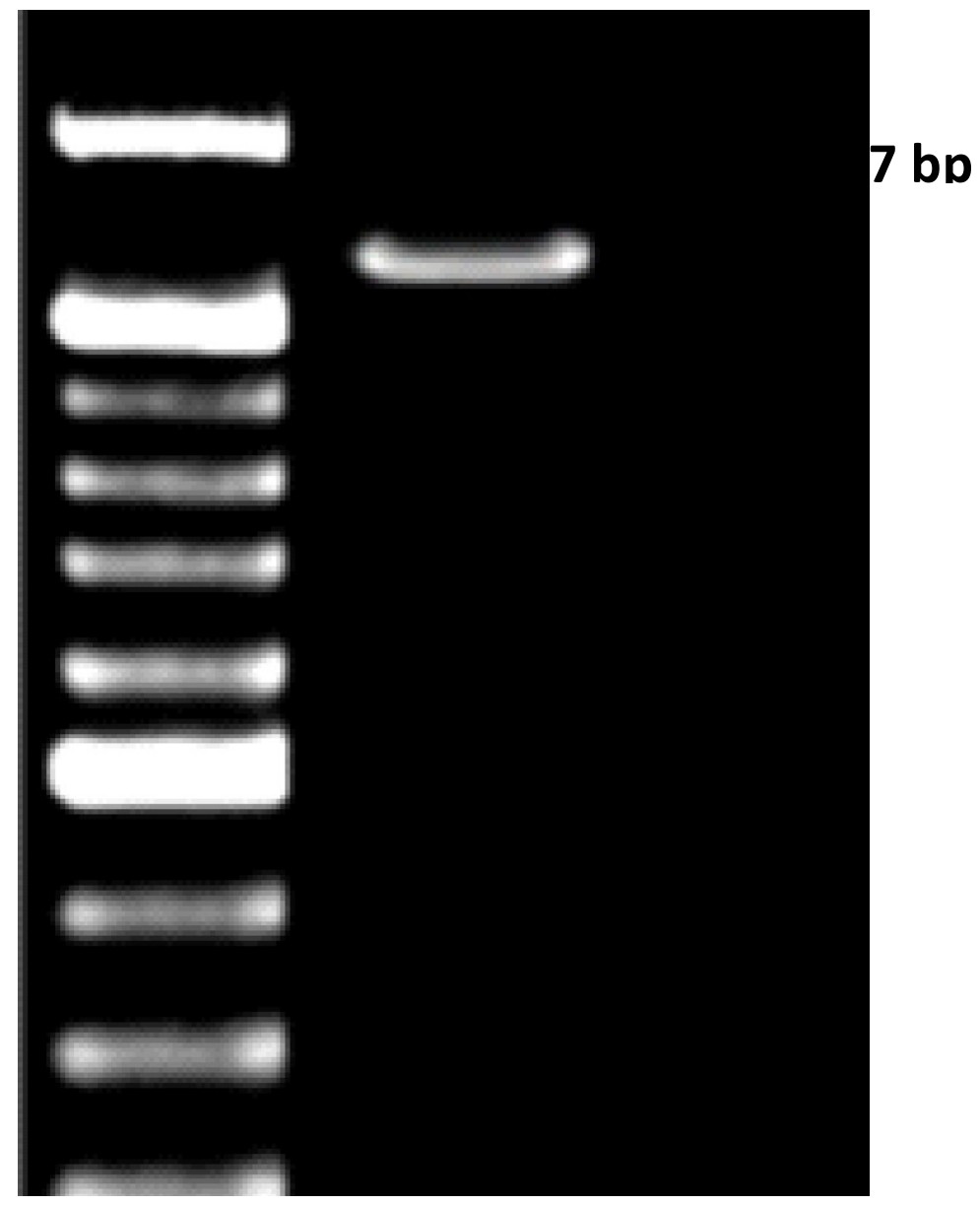

Fig 4: Electrophoretic pattern showing Semi quantitative PCR product of Cylindrotheca closterium $r b c \mathrm{~L}$ gene. 
Sequencing

GGTAATTCTA CTTATGCTCG TCAAAAAAAT CATGGGATTA ACTTCCGTGT AATTTC TGGATGCGTA TGTCAGGTGT AGATCATATT CACGCTGGTA CAGTTGTAGG TAAAT"] GGGGATCCTT TAATGATTAA AGGITITTAT CATAACTGTG GTACTTTACG GITAAC TIAGATGCTA ACTTAACAGC TICGATTATC GACAGTAACG TITITGGATT TAAAGC TCAGCTTTAC GITTAGAAGA TATGCGTATT CCACACTCAT ACTTAAAAAC ATTCC? CCGGCTACTG GIATTGIAGT AGAACGIGAA CGITTAAACA AATACGGTAC ACCAT'] GGTGCAACAG TAAAACGITA ACTTACCTTA TGGITTGITC TTCGAAATGA TTACA2 GTGGTGGTAC AATTGGTCAC CCTGATGGTA TCGIGCTAAA GCTTATCGIG TAGATC TCCAAATACA CCTGATCAAT ATITTGCATT TAITGCATAT GATGTGATT TAITTC. AGGATCTITA CAAAATTAGG TITATCTGGT AAAAACTATG GTCGTGTAGT ATTCG? TTAAAAGGTG GITTCCAGCA ACTGGTATTG TAGTAGAACG TGAGCGITTA AACAA? GTACACCATT ATTAGGTGCA ACAGTAAAAC CAAAATTAGG TTTATCTGGT AAAAAC GTCGTGTAGT ATTCGAAGGT TTAAAAGGTG GITTAGACTT CTTAAAAGAT GATGAC. ACGGCTIGTG ACCGITACCG TGCTAACATT TACACCGTGC TGGTAACTCA ACGTA] GTCAAAAAAA TCATGGTATT AACTTCCGTG TAATCTGTAA ATGGATGCGT ATGTCI TAGATCATAT CCATGCTGGT ACAGITTTAA CTCACAACCA TITATGCGIT GGAGAC.

Fig 5: Nucleotide sequence of PCR amplified ribulose-1,5-bisphosphate carboxylase/oxygenase large subunit (rbcL) gene (1177 bp) from Cylindrotheca closterium. 


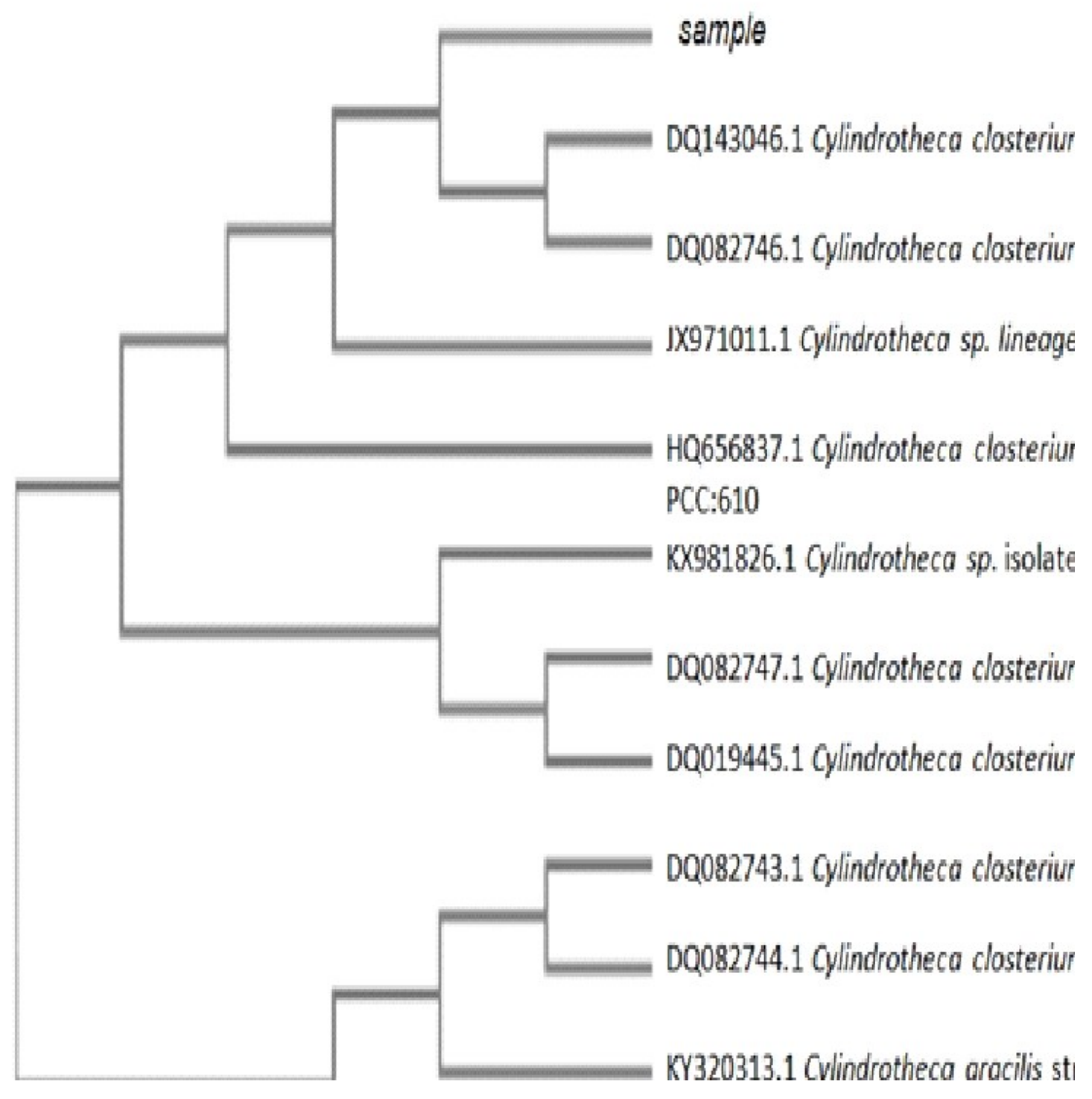

Fig 6: Nucleotide sequence alignment of PCR amplified ribulose-1,5-bisphosphate carboxylase/oxygenase large subunit ( $\mathrm{rbcL})$ gene (1177 bp) from Cylindrotheca closterium compared to related sequences in the GeneBank. 
Table (3): Identity percentage for Cylindrotheca sp according to $r b c \mathrm{~L}$ sequence.

\begin{tabular}{|l|c|c|c|c|c|c|c|c|c|c|c|c|c|}
\hline \multicolumn{1}{|c|}{ Cy_rbcl_1_ } & 100.0 & 75.91 & 75.91 & 75.91 & 76.63 & 76.49 & 78.37 & 78.37 & 74.46 & 75.18 & 76.20 & 75.62 & 75.47 \\
& & & & & & & & & & & & & \\
\hline DQ082743.1 & 75.91 & 100.0 & 99.66 & 99.83 & 95.02 & 93.87 & 95.29 & 95.38 & 94.20 & 95.46 & 94.81 & 94.71 & 94.62 \\
\hline KY320313.1 & 75.91 & 99.66 & 100.0 & 99.83 & 95.16 & 94.16 & 95.29 & 95.38 & 94.71 & 95.46 & 95.02 & 94.71 & 94.62 \\
\hline DQ082744.1 & 75.91 & 99.83 & 99.83 & 100.0 & 95.20 & 94.03 & 95.46 & 95.55 & 94.37 & 95.63 & 94.90 & 94.87 & 94.79 \\
\hline HQ656837.1 & 76.63 & 95.02 & 95.16 & 95.20 & 100.0 & 95.52 & 96.77 & 96.86 & 95.44 & 96.24 & 96.36 & 95.90 & 95.98 \\
\hline JX971011.1 & 76.49 & 93.87 & 94.16 & 94.03 & 95.52 & 100.0 & 96.97 & 97.06 & 94.93 & 94.71 & 95.73 & 95.38 & 95.29 \\
\hline DQ143046.1 & 78.37 & 95.29 & 95.29 & 95.46 & 96.77 & 96.97 & 100.0 & 99.92 & 95.46 & 95.80 & 96.33 & 96.30 & 96.39 \\
\hline DQ082746.1 & 78.37 & 95.38 & 95.38 & 95.55 & 96.86 & 97.06 & 99.92 & 100.0 & 95.46 & 95.88 & 96.42 & 96.39 & 96.39 \\
\hline JX971016.1 & 74.46 & 94.20 & 94.71 & 94.37 & 95.44 & 94.93 & 95.46 & 95.46 & 100.0 & 95.55 & 95.56 & 95.29 & 95.97 \\
\hline AY866415.1 & 75.18 & 95.46 & 95.46 & 95.63 & 96.24 & 94.71 & 95.80 & 95.88 & 95.55 & 100.0 & 96.06 & 96.39 & 96.30 \\
\hline KX981826.1 & 76.20 & 94.81 & 95.02 & 94.90 & 96.36 & 95.73 & 96.33 & 96.42 & 95.56 & 96.06 & 100.0 & 98.03 & 97.94 \\
\hline DQ82747.1 & 75.62 & 94.71 & 94.71 & 94.87 & 95.90 & 95.38 & 96.30 & 96.39 & 95.29 & 96.39 & 98.03 & 100.0 & 98.32 \\
\hline DQ019445.1 & 75.47 & 94.62 & 94.62 & 94.79 & 95.29 & 95.29 & 96.39 & 96.39 & 95.97 & 96.30 & 97.94 & 98.32 & 100.0 \\
\hline
\end{tabular}


Ribulose-bisphosphate carboxylase gene (rbcL) was applied as molecular marker to identify Cylindrotheca sp. Specific genomic product for Cylindrotheca sp. $r b c \mathrm{~L}$ gene (Approx. 1190 bp) was eluted, sequenced and alignments. Our obtaining sequence was identified as Cylindrotheca closterium with varied identity percentages $(81,80$ and $78 \%)$.Samples found to be match with Cylindrotheca closterium strain JZB-3A, and Cylindrotheca closterium strain JZB-3A, and Cylindrotheca sp. lineage IV strain OS1, and Cylindrotheca closterium strain MGB0503, and Cylindrotheca gracilisstrain TA46 with high homology percentage $81 \%$. And found to be match with Cylindrotheca closterium culture-collection PCC: 610 and Cylindrotheca $s p$. isolate UTKSA0079 and Cylindrotheca closterium strain MGB0506, and Cylindrotheca closterium strain MGB0402 with homology percentage $80 \%$. And found to be match with Cylindrotheca sp. lineage III strain OS9b with homology percentage 78\%. Constructed phyllogenetic tree indicated distinguish highly genetic similarity between our obtaining Cylindrotheca closterium with Cylindrotheca closterium strain JZB (DQ143046.1 with $78.37 \%$ of genetic similarity) and Cylindrotheca closterium strain MGB0505 (DQ082746.1 with $75.91 \%$ of genetic similarity).

\section{Discussions}

In this study Cylindrotheca closterium alga was identified morphologically using light microscope and scanning electric microscope. The specie of Cylindrotheca was motile, unicellular and thin in shape characterized by having cylindrical frustule which was fusiform. It was needle-like with a swollen center and Two ends of the cell extended far from the center of the cell, The cell was linear to lanceolate, tapering to very long projection with similar observation with (Demirel. 2016), (Haitao. et al. 2007), (Bernhard, and Joyce, 1964) there are many bands on the frustule twisted around each other in the rostrate ends; rostrate apices were extremely short barely seen under LM. With similar observation with (Kesici, et al. 2013) and (Vanormelingen, et al. 2013). The cells contained two plastids lying next to each other along the longitudinal axis of the cell and apprised to one side of the cell with lobes extending onto the other sides, and the nucleus centrally in between. Cell division was longitudinal, dividing both plastids without any obvious preceding plastid rearrangement similar to the observation of (Vanormelingen et al. 2013). The purified algae were about $50 \mu \mathrm{m}$ in length while ranged from 25 to $98 \mu \mathrm{m}$ in length and 2 to $4 \mu \mathrm{m}$ in width observed by (Haitao, et al., 2006). The length of the cells varied from $250 \mu \mathrm{m}$ to $500 \mu \mathrm{m}$ and the width ranged from $2.5 \mu \mathrm{m}$ to $8 \mu \mathrm{m}$. C. closterium was considerable the weakly silicified valves by SEM The valves were only lightly silicified this observed by (Demirel, 2016) The valves were not obviously twisted for most of their length, but there was a clear twist in the rostrate valve apices, which is typical for C. closterium (Vanormelingen, et al. 2013), we found that the cells were generally motile rotated conspicuously around their apical axes; the sense of the rotation depending on the sense of spiraling of the raphe. A slight rotation was sometimes visible in gliding cells. In some strains the cell size varied considerably, while in others it was relatively constant. The central section of each cell contained 2 flat chromatophores in the middle of the cell, one on either side of the nucleus, lying along the cell wall, not extending into the ends, that the same observation of (Bernhard and Joyce, 1964)

Genetic identification of Cylindrotheca closterium was applied using ribulosebisphosphate carboxylase gene $(r b c L)$ as molecular marker to identify Cylindrotheca sp. Specific genomic product for Cylindrotheca sp. rbcL gene (1177 bp), was eluted identified with varied identity percentages (81 and $80 \%$ ). Constructed phyllogenetic tree indicated highly genetic similarity between identified Cylindrotheca closterium and Cylindrotheca closterium strain JZB-DQ143046.1 by $78.37 \%$ of genetic similarity and between Cylindrotheca closterium strain MGB0505DQ082746.1 by $75.91 \%$ similarity. While (Haitao,A et al., 2006) obtained agenomic product 1190 nucleotides of rbcL gene and more than $90 \%$ of the variation. The ITS region sequence displayed $99 \%$ similarity with Cylindrotheca closterium sequences in 
GenBank observed by( Kesici, et al.2013), The $18 \mathrm{~S}$ rRNA gene sequence from $C$. closterium strain RCC1985 groups with the other $C$. closterium sequences forming a moderatelysupported clade (sequence similarity $>97.8 \%$ ) observed by (Sergio, et al., 2017). Cylindrotheca sp. Clones had 22 segregating sites out of a total of 655 nucleotide positions (with an estimated $96.6 \%$ sequence similarity) with a total of 11 non-synonymous substitutions.

\section{Referances}

Bernhard, E. F.; and Joyce, C. (1964). The Diatom Genus Cylindrotheca Rabenhorst with a reconsideration of Nitzschia closterium. Journal of the Royal Microscopical Society, 83: 283-296.

Demirel,Z. (2016). Identification and Fatty Acid Composition of Coccolithophore and Diatom Species Isolated from Aegean Sea, Romanian Biotechnological Letters, 21: 4

Grant, BR. Madgwick, J. and Pont, G. Dal. (1967). Growth of Cylindrotheca closterium var. .(Mereschk.)Reimann\&Lewin on nitrate, ammonia, and urea. Australian Journal of Marine and Fresh water Research 18(2) 129 136.

Guillard, R. R. L. (1975). Culture of phytoplankton for feeding marine invertebrates. In: Smith, W. L., and Chanley, M. H., eds. Culture of Marine Invertebrate Animals. Plenum Press, New York, pp. 29-60.

Haitao, L.; Guanpin, Y.; Ying, S.; Suihan, W. and Xiufang, Z. (2007). Cylindrotheca closterium is a species complex as was evidenced by the variations of rbcL gene and SSU Rdna. Journal of Ocean University of China, 6(2): 167-174.

Hendey, N. I. (1964). Bacillariophyceae (Diatoms). An introductory account of the smaller Algae of british coastal waters (Ministry of Agriculture, Fisheries and Food,editors), Otto Koeltz Science Publishers, Koenigstein.

Kesici1, K.; Tüney, I.; Zeren, D.; Güden, M. and Sukata, A.(2013). Morphological and molecular identification of pennate diatoms isolated from Urla,İzmir, coast of the Aegean Sea ,Turkish Journal of Biology 37: 530-537.

Mann, D.G. (1989). The species concept in diatoms: Evidences for morphologically distinct, sympatric gamodemes in four epipelic species". Plant Systematics and Evolution. Springer Science+Business Media. 164 (1-4): 215-237.

Round, F. E.(1981). The ecology of algae. Cambridge UniversityPress, Cambridge, UK. $653 \mathrm{pp}$

Sergio, B.; Isabella,P.; Raffaele,S.; Priscillia, G.; Mélanie,C.; Marie,D.;Daniel,V. and Diana,S.(2017). Morphological and genetic diversity of Beaufort Sea diatoms with high contributions from the Chaetocerosneogracilis species complex, Journal of Phycology, 53 (1): 161-187

Spaulding, S. and Edlund, M. (2008). Cylindrotheca. In Diatoms of the United States from

http://westerndiatoms.colorado.edu/taxa/genus/ Cylindrotheca.

Stein, J. R., (1973). Handbook of Phycological Methods. Culture Methods and Growth Measurements. Cambridge University Press, Cambridge, 448 pp.

Treguer, P.; Nelson, D.M.; van Bennekom, J.V.; DeMaster, D.J.; Leynaert, A. and Que'guiner, B. (1995). The silica balance in the world Ocean: a reestimate. Science 268: 375 379.

Vanormelingen, P.; Vanelslander, B.; Sato, S.; Gillard, J.; Trobajo, R.; Sabbe, K.; And Vyverman, W. (2013). Heterothallic sexual reproduction in the model diatom Cylindrotheca J. Phycol. 48(1): 93-105

Negrisolo, E.S.; Maistro, M.; Incarbone, I.; Moro, L. D. and Vall (2004). Morphological convergence characterizes theevolution of Xanthophyceae (Heterokontophyta): evidence from nuclear SSU rdna and plastidial rbcl genes. Mol. Phylogenet. Evol., 33: 156-17 